\begin{tabular}{|c|c|c|}
\hline BIODIK & $\begin{array}{c}\text { BIODIK: Jurnal IImiah Pendidikan Biologi } \\
\text { ISSN 2580-0922 (online), ISSN 2460-2612 (print) } \\
\text { Volume 7, Nomor 02, Tahun 2021, Hal. 163-168 } \\
\text { Available online at: } \\
\text { https://online-journal.unja.ac.id/biodik }\end{array}$ & BIODIK \\
\hline
\end{tabular}

Research Article

\title{
Analisis Kendala Pembelajaran Online Selama Pandemi Covid-19 Pada Mata Pelajaran IPA di SMPN 1 Bayung Lencir
}

\section{(Analysis of the Obstacles of Online Learning During the Covid-19 Pandemic on IPA Subjects at SMPN 1 Bayung Lencir)}

\section{Muhamad Sholichin*, Zulyusri, Lufri, Abdul Razak}

Megister Pendidikan Biologi, Universitas Negeri Padang

Jl. Prof. Dr. Hamka, Air Tawar Bar., Kec. Padang Utara, Kota Padang, Sumatera Barat 25171

Corresponding Authors : akulihin24@gmail.com

\begin{tabular}{|c|c|}
\hline Informasi Artikel & ABSTRACT \\
\hline $\begin{array}{l}\text { Submit: } 10-03-2021 \\
\text { Diterima: } 24-05-2021 \\
\text { Dipublikasikan: } 10-06-2021\end{array}$ & $\begin{array}{l}\text { This study aims to determine the obstacles to online learning at SMP Negeri } 1 \\
\text { Bayung Lencir during the Covid-19 pandemic in science subjects. Changes in } \\
\text { learning methods that were originally carried out face-to-face to online learning } \\
\text { experienced several obstacles starting an unstable internet network, an } \\
\text { inadequate internet quota so that students' lack of understanding of the subject } \\
\text { matter provided. This type of research is a descriptive survey research with a } \\
\text { qualitative approach, the data of this study were obtained from students of } \\
\text { class VIII and IX. The data collection technique in this study was a } \\
\text { questionnaire while the instrument used in this study was an online } \\
\text { questionnaire distributed through the WhatsApps application. The data analysis } \\
\text { technique used in this research is descriptive analysis. The results showed that } \\
\text { the constraints most experienced by the students of SMP Negeri } 1 \text { Bayung } \\
\text { Lencir were the lack of internet quota and an unstable internet network. } \\
\text { Key words: Analysis, Online Learning, The Covid-19 Pandemic }\end{array}$ \\
\hline Penerbit & ABSTRAK \\
\hline $\begin{array}{l}\text { Program Studi Pendidikan Biologi } \\
\text { FKIP Universitas Jambi, } \\
\text { Jambi- Indonesia }\end{array}$ & $\begin{array}{l}\text { Penelitian ini bertujuan untuk mengetahui kendala pembelajaran online di SMP } \\
\text { Negeri } 1 \text { Bayung Lencir selama pandemi Covid-19 pada mata pelajaran IPA. } \\
\text { Perubahan metode pembelajaran yang semula dilakukan secara tatap muka } \\
\text { menjadi pembelajaran online mengalami beberapa kendala memulai jaringan } \\
\text { internet yang kurang stabil, kuota internet yang kurang memadai sehingga } \\
\text { kurangnya pemahaman peserta didik terhadap materi pelajaran yang diberikan. } \\
\text { Jenis penelitian ini yaitu penelitian survey deskriptif dengan pendekatan } \\
\text { kualitatif, data penelitian ini diperoleh dari siswa kelas VIII dan IX. Teknik } \\
\text { pengumpulan data pada penelitian ini adalah angket (kuesioner) sedangkan } \\
\text { instrumen yang digunakan pada penelitian ini adalah angket (kuesioner) online } \\
\text { yang disebarkan melalui aplikasi WhatsApps. Teknik analisis data yang } \\
\text { digunakan dalam penelitian ini yaitu analisis deskriptif. Hasil penelitian } \\
\text { menunjukkan bahwa kendala yang paling banyak dirasakan oleh peserta didik } \\
\text { SMP Negeri } 1 \text { Bayung Lencir adalah kendala kurangnya kuota internet dan } \\
\text { jaringan internet yang tidak stabil. } \\
\text { Kata kunci: Analisis, Pembelajaran Online, Pandemi Covid-19 }\end{array}$ \\
\hline
\end{tabular}




\section{PENDAHULUAN}

Pada tahun 2020 hampir seluruh Negara berdampak terkena wabah Covid-19, Indonesia salah satu Negara yang terpapar Virus ini. Untuk meminimalisir penyebaran Virus pemerintah menerapkan Work From Home (WFH) sampai Pembatasan Sosial Bersekala Besar bagi daerah yang berada pada kategori zona merah. Untuk menindak lanjuti arah pemerintah, pada tanggal 24 Maret 2020 Kementrian Pendidikan dan Kebudayaan mengeluarkan surat Edaran No.4 tahun 2020. Surat ini berisi arahan pembelajaran diharuskan dari rumah atau dalam jaringan (daring) baik jenjang Pendidikan dasar sampai tingkat Universitas (Muafiah. A \& Nasrah, 2020).

Pada tahun 2020 telah terjadi pandemi Covid - 19 yang menyebabkan semuanya berubah pembelajaran yang dilaksanakan disekolah berubah sesuai dengan aturan pemerintah dilaksanakan dirumah dengan daring atau belajar dengan jarak jauh (Suriadi et al., 2021). Selama belajar dari rumah, siswa banyak mendapatkan tugas. Belum lagi, peran orang tua yang harus mengawasi proses pembelajaran anaknya selama di rumah (Mustofa et al., 2019). Pembelajaran daring ternyata bukanlah hal yang bisa dilakukan dengan mudah apalagi bagi mereka yang tidak memiliki jaringan yang kuat untuk melaksanakan pembelajaran daring terlebih bagi sekolah yang berada didaerah pedalaman yang tidak terjangkau oleh jaringan (Atiqoh, 2020).

Covid-19 telah mengubah gaya hidup orang di seluruh dunia, orang-orang disarankan untuk menjaga jarak dan membatasi perjalanan sesering mungkin. Dan langkah-langkah keamanan ini juga berlaku untuk dunia pendidikan (Handayani, 2020). Sebagai elemen penting dalam pengajaran, guru dan peserta didik diharuskan melakukan adaptasi dengan mengubah pendidikan tatap muka tradisional (luring) ke pendidikan daring atau pendidikan jarak jauh (Bao, 2020).

Guru sebagai garda terdepan dalam pendidikan memiliki tugas untuk mengajar, mendidik, memberikan penilaian dan evaluasi hingga memberikan dukungan moral dan mental kepada peserta didik. Proses belajar mengajar yang dilaksanakan oleh guru dan peserta didik biasanya dilakukan di sekolah atau melalui interaksi langsung tanpa media perantara apapun. Namun dalam beberapa bulan terakhir tugas guru yang disebutkan sebelumnya mengalami perubahan dalam proses pembelajarannya, hal tersebut terjadi karena sebuah wabah yang menyerang dunia termasuk Indonesia (Putria et al., 2020).

Walaupun pendidikan tatap muka tidak bisa dilakukan, pembelajaran wajib senantiasa berjalan dengan mengalihkan metode pendidikan tatap muka jadi pembelajaran online. SMP Negara 1 Bayung Lencir ialah salah satu sekolah yang terletak di Kecamatan Bayung Lencir yang mempraktikkan kebijakan tersebut. Pembelajaran secara online menjadi metode baru dalam kegiatan belajar mengajar yang memanfaatkan perangkat elektonik dan jaringan internet. Pembelajaran online atau pembelajaran virtual dianggap sebagai paradigma baru dalam proses pembelajaran karena dapat dilakukan cara yang sangat mudah tanpa harus bertatap muka dan hanya mengandalkan sebuah aplikasi berbasis koneksi internet maka proses pembelajaran dapat berlangsung (Adijaya \& Santosa, 2018).

Abdusshomad, (2020) mengemukakan bahwa pembelajaran daring ialah proses pembelajaran yang dilakukan dengan memanfaatkan berbagai fitur seperti smartphone, teknologi digital, laptop, web atau aplikasi berbasi internet atau jaringan. Handayani, (2020) menjelaskan keuntungan dari 
pembelajaran daring adalah waktu tidak terbatas, masih banyak waktu luang dan menghemat biaya transportasi. Akan tetapi dalam praktinya, pembelajaran daring tidak semaksimal pembelajaran dikelas.

Bagi guru yang terbiasa melakukan proses belajar mengajar secara tatap muka, kondisi ini memunculkan berbagai kendala seperti ketidaksiapan pembelajaran. Perubahan yang terjadi secara cepat akibat penyebaran Covid-19 membuat guru harus faham akan tekhnologi. Melalui tekhnologi inilah salah satu penghubung bagi guru dan siswa melakukan pembelajaran tanpa harus melakukan pembelajaran tatap muka.

Pembelajaran daring merupakan tantangan tersendiri bagi peserta didik, Jayul \& Irwanto, (2020) mengemukakan bahwa proses pembelajaran merupakan proses komunikasi, yaitu proses penyampaian pesan dari sumber pesan melalui saluran/media tertentu ke penerima pesan pembelajaran daring, karena pada dasarnya proses pembelajaran merupakan suatu kombinasi yang yang tersusun meliputi unsur-unsur manusiawi, material, fasilitas, perlengkapan dan prosedur yang saling mempengaruhi mencapai tujuan pembelajaran. Berdasarkan permasalahan yang telah diuraikan sebelumnya, maka peneliti terdorong untuk meneliti apa saja kendala yang terjadi pada saat proses pembelajaran online pada masa pandemi Covid-19. Kendala-kendala tersebut menjadi hal penting yang pelu dikaji guna kelancara pembelajaran online.

\section{METODE PENELITIAN}

Penelitian ini dilaksanakan pada tanggal 30 November 2020 di kelas VIII dan IX SMP Negeri 1 Bayung Lencir yang telah menerapkan kebijakan pembelajaran online. Tujuan penelitian ini adalah untuk mengetahui apa saja kendala yang dihadapi pada saat pembelajaran daring yang diselenggarakan di SMP Negeri 1 Bayung Lencir sebagai upaya dalam menekan mata rantai penyebaran Covid-19.

Penelitian ini menggunakan pendekatan kualitatif dan merupakan jenis penelitian survey deskriptif. Penelitian survey merupakan penelitian yang mengambil sampel dari satu populasi dan menggunakan kuesioner sebagai alat pengumpulan data yang pokok (Adiyanta, 2019). Subjek penelitian ini adalah siswa kelas VIII dan IX SMP Negeri 1 Bayung Lencir yang telah melaksanakan pembelajaran daring, dan dikelompokkan berdasarkan respon subjek penelitian. Di dapatkan 67 orang subjek penelitian dari siswa kelas VIII dan IX SMP Negeri 1 Bayung Lencir. Pengumpulan data dilakukan melalui angket (kuesioner) online dalam Google Form yang disebarkan memalui aplikasi WhatsApps kepada siswa kelas VIII dan IX SMP Negeri 1 Bayung Lencir dianalisis secara deskriptif. Analisis data penelitian dilakukan menggunakan model analisis (Miles \& Huberman, 1994) yang terdiri dari tiga tahapan, yaitu reduksi data, display data, serta penarikan dan verifikasi kesimpulan.

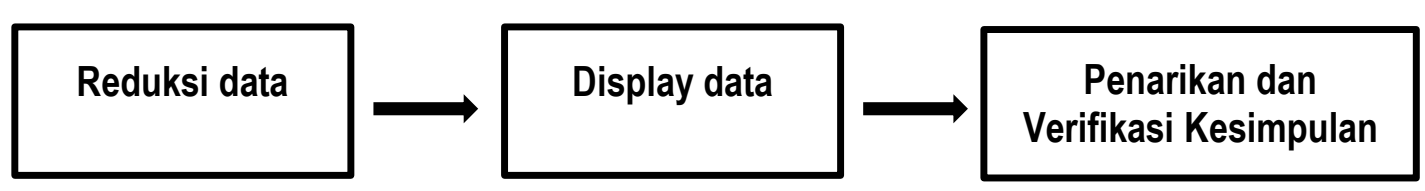

Gambar 1 : Tahapan Analisis Data Penelitian 
Analisis data penelitian tahap reduksi data merupakan tahap mengumpulkan seluruh informasi yang dibutuhkan dari hasil wawancara lalu di kelompokkan datanya. Tahap display data merupakan pemaparan data yang diperlukan dalam penelitian dan yang tidak perlu dibuang. Tahap penarikan dan verifikasi kesimpulan adalah tahap interpretasi data penelitian untuk ditarik kesimpulan berdasarkan fenomena yang didapatkan (Miles \& Humberman, 1994).

\section{HASIL PENELITIAN DAN PEMBAHASAN}

Hasil penelitian menunjukkan bahwa sejak awal tahun ajaran baru 2020/2021 SMP Negeri 1 Bayung Lencir mulai menerapkan pembelajaran online. Seperti yang telah disampaikan oleh Kementrian Pendidikan dan Kebudayaan pada surat edaran No.4 tahun 2020 yang berisi tentang arahan pembelajaran diharuskan dari rumah atau dalam jaringan (daring). Platform yang sering digunakan pada saat pembelajaran online di SMP Negeri 1 Bayung Lencir adalah WhatsApps dan Google Clasroom. Berdasarkan data yang diperoleh dari kuesioner maka kendala yang dihadapi pada saat pembelajaran online di SMP Negeri 1 Bayung Lencir adalah kurangnya memahami materi yang diberikan oleh guru, jaringan internet yang kurang stabil dan tugas yang diberikan guru terlalu banyak. Fauzy \& Nurfauziah, (2021) mengemukakan bahwa kebanyakan siswa menggunakan WhatsApp sebagai media saat pembelajaran daring, kendala umum yang di alami siswa selama pembelajaran daring di dominasi jaringan internet yang tidak memadai dan memori HP yang penuh. Hal tersebut bisa dilihat pada hasil survey di bawah ini.

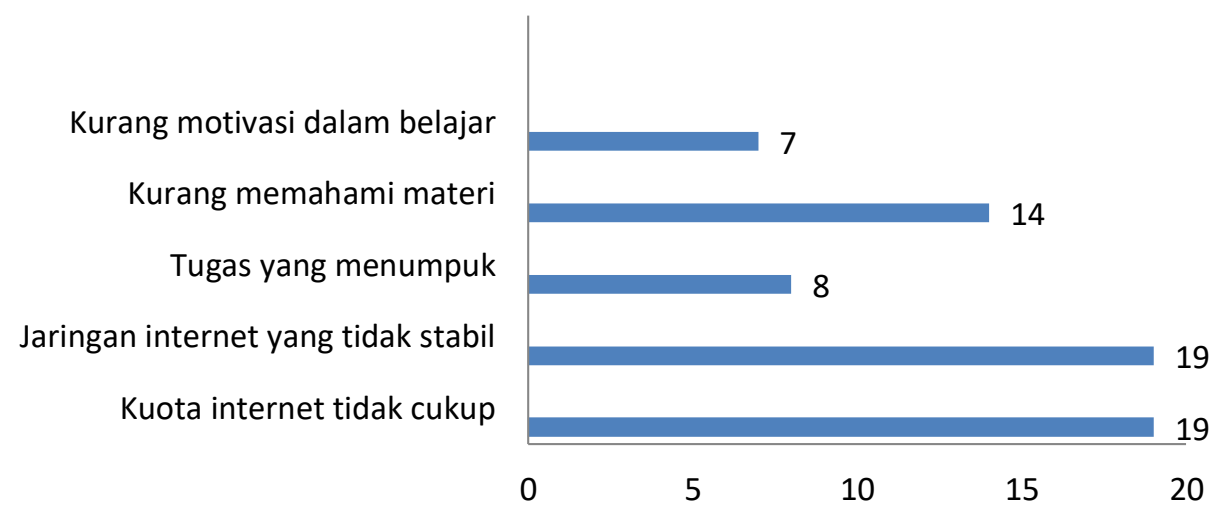

Gambar 2 : Kendala Yang Dialami Oleh Peserta Didik SMP Negeri 1 Bayung Lencir Pada Saat Pembelajaran Online

Proses pembelajaran di sekolah merupakan alat kebijakan publik terbaik sebagai alat peningkatan pengetahuan dan skill. Selain itu banyak siswa menganggap bahwa sekolah adalah kegiatan yang sangat menyenangkan, mereka bisa berinteraksi satu sama lain. Sekolah dapat meningkatkan keterampilan sosial dan kesadaran kelas sosial siswa. Sekolah secara keseluruhan adalah media interaksi antar siswa dan guru untuk meningkatkan kemampuan integensi, skill dan rasa kasih sayang diantara mereka. Tetapi sekarang kegiatan yang bernama sekolah berhenti dengan tibatiba karena gangguan Covid-19 (Baharin, dkk. 2020).

Seperti yang kita ketahui, bahwa pandemi Covid-19 telah menyebar keseluruh dunia dan memberikan dampak pada berbagai aspek, salah satunya yaitu aspek pendidikan. Dengan munculnya 
pengalihan model pembelajaran yang baru maka tak dapat dipungkiri munculnya kendala/hambatan saat pembelajaran online. Kendala tersebut berupa kuota internet yang kurang memadai, jaringan internet yang tidak stabil, tugas yang menumpuk, kurang memahami materi dan kurangnya motivasi belajar (Amalia et al., 2020).

Pembelajaran online tidak bisa lepas dari kendala/hambatan, begitu juga pada peserta didik di SMP Negeri 1 Bayung Lencir. Berdasarkan Gambar 1. Kendala yang dialami oleh peserta didik SMP Negeri 1 Bayung Lencir menunjukkan bahwa sebanyak 19 peserta didik $(63,3 \%)$ mengalami kendala berupa kuota internet yang kurang memadai, 19 peserta didik $(63,3 \%)$ mengalami kendala berupa jaringan internet yang kurang stabil, 8 peserta didik $(26,7 \%)$ mengalami kendala tugas yang diberikan guru terlalu banyak, 14 peserta didik $(46,7 \%)$ mengalami kendala berupa kurang memahami materi, 7 peserta didik $(23,3 \%)$ mengalami kendala berupa kurangnya motivasi untuk belajar. Hal ini menunjukkan bahwa kebanyakan peserta didik mengalami kendala berupa layanan jaringan internet dan kuota yang kurang memadai. Hal ini sejalan dengan penelitian Sadikin et al., (2020) yang mengatakan bahwa tantangan dalam pembelajaran daring atau secara online ini diantaranya yaitu ketersediaan layanan internet dan kuota yang kurang memadai dikarenakan pembelian kuota data internet mengeluarkan biaya yang cukup mahal.

Sebagaimana yang dijelaskan oleh Napitupulu, (2020) bahwa ketidak puasan terbesar dengan pembelajaran online adalah karena ketidak stabilan jaringan, dan siswa dikutip mengalami kesulitan jaringan yang menganggu kelas mereka. Jaringan merupakan faktor penting bagi lingkungan pembelajaran online. Siswa menyoroti peningkatan jaringan, yang melayani ruang kelas pembelajaran online, sebagai pertimbangan penting. Dalam pembelajaran jarak jauh, jaringan tidak hanya merupakan metode untuk mendistribusikan materi pendidikan, tetapi juga sarana untuk mempromosikan interaksi antara guru dan siswa atau di antara siswa.

Pembelajaran online lebih mengarah pada student centered sehingga mampu memunculkan tanggung jawab dalam belajar, sehingga membuat peserta didik lebih mampu menumbuhkan kemandirian dalam belajar (Handarini \& Wulandari, 2020). Cara guru dalam memanfaatkan faktor pendukung dalam pembelajaran online adalah memaksimalkan penggunaanya dengan cara mencari media pembelajaran berupa video serta terus mengikuti perkembangan atau kemajuan peserta didik dalam mengikuti pembelajaran online (Purwanto et al., 2020).

\section{SIMPULAN}

Meskipun pembelajaran tatap muka tidak dapat dilakukan, pendidikan harus tetap berjalan dengan cara mengalihkan pembelajaran tatap muka menjadi pembelajaran online. Pembelajaran online tentu saja tidak terlepas dari kendala pada proses pembelajaran. Bersumber pada hasil riset serta analisis ulasan bisa disimpulkan kalau hambatan peserta didik dalam pembelajaran online di SMP Negara 1 Bayung Lencir merupakan hambatan kuota internet yang kurang mencukupi serta jaringan internet yang tidak normal.

\section{RUJUKAN}

Abdusshomad, A. (2020). Pengaruh Covid-19 terhadap Penerapan Pendidikan Karakter dan Pendidikan Islam. QALAMUNA: Jurnal Pendidikan, Sosial, Dan Agama, 12(2), 107-115. https://doi.org/10.37680/qalamuna.v12i2.407 
Adijaya, N., \& Santosa, L. P. (2018). Persepsi Mahasiswa Dalam Pembelajaran Online. 10(2).

Adiyanta, F. C. S. (2019). Hukum dan Studi Penelitian Empiris : Penggunaan Metode Survey sebagai Instrumen Penelitian Hukum Empiris. 2(4), 697-709.

Amalia, R. U., Isnaeni, B., \& Hanafi, Y. (2020). ANALISIS KENDALA PESERTA DIDIK DALAM PEMBELAJARAN ONLINE MATERI BIOLOGI DI SMP NEGERI 3 BANTUL. 5, 10-15.

Atiqoh, L. N. (2020). Respon Orang Tua Terhadap Pembelajaran Daring Pada Masa Pandemi Covid-19. Thufuli: Jurnal IImiah Pendidikan Islam Anak Usia Dini, 2(1), 45. https://doi.org/10.33474/thufuli.v2i1.6925

Bao, W. (2020). COVID-19 and online teaching in higher education : A case study of Peking University. March, 113-115. https://doi.org/10.1002/hbe2.191

Eskploratif, S. (2020). Keuntungan, Kendala dan Solusi Pembelajaran Online Selama Pandemi Covid19: Studi Ekploratif di SMPN 3 Bae Kudus Lina Handayani. 1(2), 15-23.

Fauzy, A., \& Nurfauziah, P. (2021). Kesulitan Pembelajaran Daring Matematika Pada Masa Pandemi COVID-19 di SMP Muslimin Cililin. Jurnal Cendekia: Jurnal Pendidikan Matematika, 5(1), 551561. https://doi.org/10.31004/cendekia.v5i1.514

Handarini, O. I., \& Wulandari, S. S. (2020). Pembelajaran Daring Sebagai Upaya Study From Home ( SFH ) Selama Pandemi Covid 19 Pembelajaran Daring Sebagai Upaya Study From Home ( SFH) ..... 8(1), 496-503.

Harapan, U. P. (2020). Universitas muhammadiyah enrekang. 2, 1-12.

Jayul, A., \& Irwanto, E. (2020). Model Pembelajaran Daring Sebagai Alternatif Proses Kegiatan Belajar Pendidikan Jasmani di Tengah Pandemi Covid-19 Achmad. Jurnal Pendidikan Kesehatan Rekreasi, 6(2), 190-199.

Mustofa, M. I., Chodzirin, M., \& Sayekti, L. (2019). Formulasi Model Perkuliahan Daring Sebagai Upaya Menekan Disparitas Kualitas Perguruan Tinggi (Studi terhadap Website pditt.belajar.kemdikbud.go.id). Walisongo Journal of Information Technology, 1(2), 151-160.

Miles, M. B., \& Huberman, M. (1994). Qualitative Data Analysis Second Edition. SAGE Publications.

Napitupulu, R. M. (2020). Dampak pandemi Covid-19 terhadap kepuasan pembelajaran jarak jauh. Jurnal Inovasi Teknologi Pendidikan, 7(1), 23-33. https://doi.org/10.21831/jitp.v7i1.32771

Pada, M., \& Pandemik, M. (2020). Jurnal Riset Pendidikan Dasar. 03(2), 207-213.

Putria, H., Maula, L. H., \& Uswatun, D. A. (2020). Analisis Proses Pembelajaran dalam Jaringan (DARING) Masa Pandemi Covid- 19 Pada Guru Sekolah Dasar. Jurnal Basicedu, 4(4), 861-870. https://doi.org/10.31004/basicedu.v4i4.460

Sadikin, A., Hamidah, A., Pinang, K., Jl, M., Ma, J., Km, B., Indah, M., Jaluko, K., Kode, K. M., \& Indonesia, P. (2020). Pembelajaran Daring di Tengah Wabah Covid-19 (Online Learning in the Middle of the Covid-19 Pandemic ). 6(1), 214-224.

Suriadi, H. J., Firman, F., \& Ahmad, R. (2021). Analisis Problema Pembelajaran Daring Terhadap Pendidikan Karakter Peserta Didik. Edukatif: Jurnal IImu Pendidikan, 3(1), 165-173. 